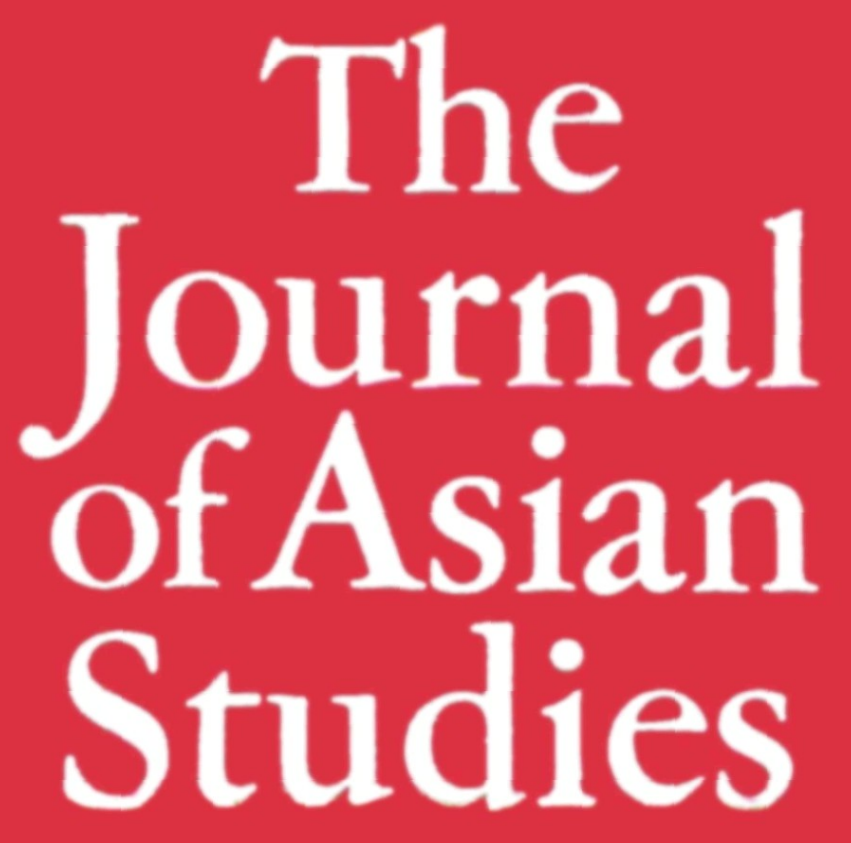

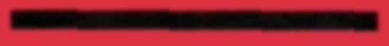

VOLUME 57

NUMBER 4

NOVEMBER 1998

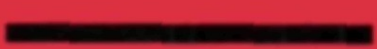

PUBLISHED BY

THE ASSOCIATION

FOR ASIAN STUDIES, INC. 


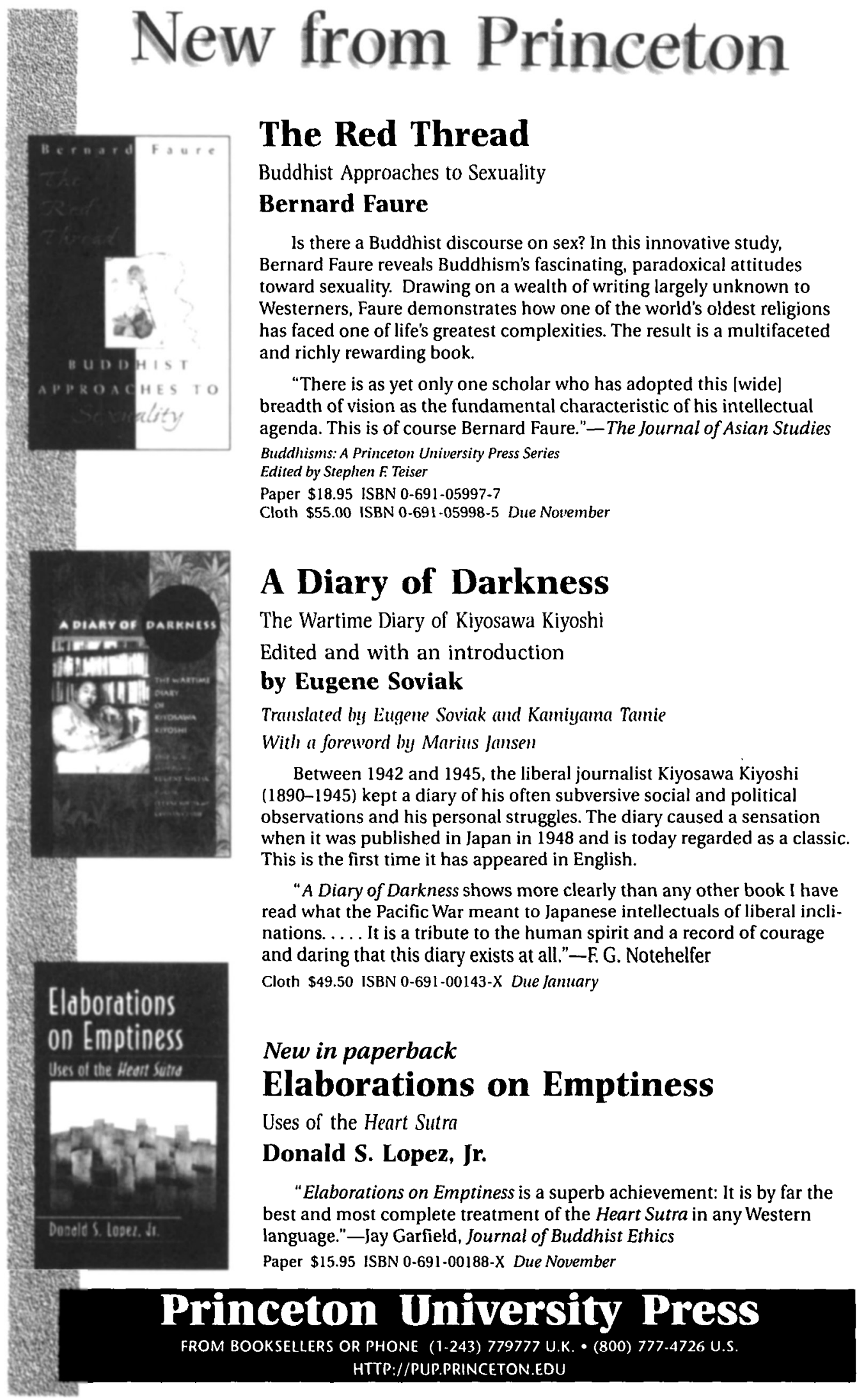




\section{The \\ Journal \\ of Asian \\ Studies}

Volume $57 \cdot$ Number $4 \cdot$ November 1998

\section{Contents}

In this Issue 947

Articles

Surface Orientations in Vietnam: Beyond Histories of Nation and Region

K. W. TAYLOR

The Poetics of Grief and the Price of Hemp in Southwest China

ERIK MUEGGLER

Tempest Over Teapots: The Vilification of Teahouse Culture in Early Republican China

QIN SHAO

Feng Meng-Lung's Treasury of Laugbs: Humorous Satire on SeventeenthCentury Chinese Culture and Society HSU PI-CHING

Partition, Pakistan, and South Asian History: In Search of a Narrative DAVID GILMARTIN

Communication the Editor 1096

Book Reviews

General Asia

Crossette, The Great Hill Stations of Asia

DANE KENNEDY

1098

EMBREE and GluCK (eds.), Asia in Western and World History: A Guide for Teaching MELISSA MACAULEY

FRITH (ed.), Advertising in Asia: Communication, Culture, and Consumption

NANCY WONG

HAYHOE and PAN (eds.), East-West Dialogue in Knowledge and Higher Education BARRY KEENAN

HeWA and Hove (eds.), Pbilantbropy and Cultural Contexts: Western Pbilanthropy in South, East, and Soutbeast Asia in the 20th Century YOICHI AIZA WA

KIM, Douglass, CHOE, and Ho (eds.), Culture and the City in East Asia YUE-MAN YEUNG

KOW ALEWSKI, Global Establishment: The Political Economy of North/Asian Networks 
LEWIS and WIGEN, The Myth of Continents: A Critique of Metageography

MARCIA YONEMOTO

ZhaO, Power Competition in East Asia

JIANWEI WANG

1110

China

AвBAs, Hong Kong: Culture and the Politics of Disappearance

GORDON MATHEWS

CAI, The Matrix of Lyric Transformation: Poetic Mode and Self-Preservation in Early Chinese Pentasyllabic Poetry JUI-LUNG SU

Clayton, Imperialism Revisited: Political and Economic Relations between Britain and China, 1950-54

ROBERT BICKERS

DENG, Private Education in Modern China

KA HO MOK

1116

ENGLISH-LuECK, Chinese Intellectuals on the World Frontier: Blazing the Black Path

LAWRENCE R. SULLIVAN

GAR Ver, Face Off: China, the United States, and Taiwan's Democratization

BYRON S. J. WENG

Goldstein, The Snow Lion and the Dragon: China, Tibet, and the Dalai Lama

JAMES D. SEYMOUR

HOW LAND, Borders of Chinese Civilization: Geography and History at Empire's End PETER ZARROW

Huters, WONG, and Yu (eds.), Culture and State in Chinese History: Conventions, Accommodations, and Critiques

PRASENJIT DUARA

JACKA, Women's Work in Rural China: Change and Continuity in an Era of Reform NORMA DIAMOND

Keating, Two Revolutions: Village Reconstruction and the Cooperative Movement in Northern Shaanxi, 1934-1945 STEPHEN AVERILL

KIPNIS, Producing Guanxi: Sentiments, Self, and Subculture in a North China Village

LloYD, Adversaries and Authorities: Investigations into Ancient Greek and Chinese Science

NiU-NiU, No Tears for Mao: Growing Up in the Cultural Revolution

KING-FAI TAM

PerRy and Lu (eds.), Danwei: The Changing Chinese Workplace in Historical Perspective CORINNA-BARBARA FRANCIS

Shaughnessy, Before Confucius: Studies in the Creation of Chinese Classics

DAVID SCHABERG

SH1, Political Participation in Beijing

MELANIE MANION

Wa Keman, Policing Shanghai, 1927-1937

DAVID STRAND

WIDMER and CHANG (eds.), Writing Women in Late Imperial China

PAUL ROUZER

YAN, The Flow of Gifts: Reciprocity and Social Networks in a Chinese Village

ZWEIG, Freeing China's Farmers: Rural Restructuring in the Reform Era

Inner Asia

Gyatso (trans.), Apparitions of the Self: The Secret Autobiographies of a Tibetan Visionary, A Translation and Study of Jigme Lingpa's Dancing Moon in the Water and Dākki's Grand Secret Talk ROGER JACKSON 
KARMAY and SAGANT (eds.), Les habitants du toit du monde: Études recueillies en bommage à Alexander W. Macdonald LEONARD W. J. VAN DER KUIJP

LOPEZ JR., Prisoners of Shangri-la: Tibetan Buddhism and the West

SHIRENDEV; ONON (trans.), Through the Ocean Waves: The Autobiography of Bazaryn Sbirendev CHRISTOPHER ATWOOD

Japan

Amstutz, Interpreting Amida: History and Orientalism in the Study of Pure Land Buddhism

JAMES C. DOBBINS

Denoon, Hudson, MCCORMACK, and Morris-Suzuki (eds.), Multicultural Japan: Palaeolithic to Postmodern JOSHUA BRESLAU

Desser (ed.), Ozu's Tokyo Story DONALD KIRIHARA

GAO, Economic Ideology and Japanese Industrial Policy: Developmentalism from 1931 to 1965 ANDREW E. BARSHAY

GARON, Molding Japanese Minds: The State in Everyday Life KWEKU AMPIAH

Hardacre and Kern (eds.), New Directions in the Study of Meiji Japan MARVIN MARCUS

Hayashi; Brown (trans.), I Saw a Pale Horse and Selected Poems from Diary of a Vagabond JOAN E. ERICSON

KARAN and Stapleton (eds.), The Japanese City RONALD SULESKI

KERR, Lost Japan DAVID L. MAJOR

KOTABE and WHEILER, Anticompetitive Practices in Japan: Their Impact on the Performance of Foreign Firms LEONARD J. SCHOPPA

MACKIE, Creating Socialist Women in Japan: Gender, Labour, and Activism, $1900-1937$

SALLY A. HASTINGS

RICHIE, The Films of Akira Kurosawa

DAVID DESSER

SAnder (ed.), The Confusion Era: Art and Culture in Japan During the Allied Occupation, 1945-52

MICHAEL S. MOLASKY

Shinran; Hirota et Al. (trans.), The Collected Works of Shinran

GALEN AMSTUTZ

Shirane, Traces of Dreams: Landscape, Cultural Memory, and the Poetry of Bashō STEVEN D. CARTER

WADA, The Japanese Election System

RAY CHRISTENSEN

YAmAKAZI, Individualism and the Japanese: An Alternative Approach to Cultural Comparison

DAVID A. TITUS

YOUNG, Japan's Total Empire: Manchuria and the Culture of Wartime Imperialism E. BRUCE REYNOLDS 
Korea

Hwang; Suh and Pickering (trans.), The Descendants of Cain

BARBARA CHARLESWORTH GELPI

SHIN, The Trap of History: Understanding Korean Short Stories

DAVID R. MCCANN

South Asia

Bose, The Challenge in Kashmir: Democracy, Self-Determination and a Just Peace ROBERT G. WIRSING

BUCHY, Teak and Arecanut: Colonial State, Forest and People in the Western Ghats (South India), 1800-1947 RICHARD P. TUCKER

CHADDA, Etbnicity, Security, and Separatism in India MARTHA CRENSHAW

Chari, Pbilosophy and Theistic Mysticism of the Alvārs FRANCIS X. CLOONEY

Dalmia, The Nationalization of Hindu Traditions: Bhāratendu Hariścbandra and Nineteentb-century Banaras KATHRYN HANSEN

DE LANNOY, The Kulasekbara Perumals of Travancore: History and State Formation in Travancore from 1671 to 1758 KATE BRITTLEBANK

DREZE and SEN (eds.), Indian Development: Selected Regional Perspectives JOHN ECHEVERRI-GENT

DWIVEDI, India's Environmental Policies, Programmes, and Stewardship

K. SIVARAMAKRISHNAN

Fernandes, Producing Workers: The Politics of Gender, Class, and Culture in the Calcutta Jute Mills GERALDINE FORBES

HeItZman, Gifts of Power: Lordsbip in an Early Indian State

DAUD ALI

JHA, Hewison, and Underhill (eds.), Trade, Environment, and Sustainable Development: A South Asian Perspective K. SIVAR AMAKRISHNAN

KULKe and ROTHERMUND, History of India GEORGE W. SPENCER

Low, Britain and Indian Nationalism: The Imprint of Ambiguity, 1919-1942

MCLEAN, Devoted to the Goddess: The Life and Work of Ramprasad RACHEL FELL MCDERMOTT

MITRA and LewIS (eds.), Subnational Movements in Soutb Asia

RACINe (ed.), Peasant Moorings: Village Ties and Mobility Rationales in South India

Ramanujan; Blackburn and Dundes (eds.), The Flowering Tree and Other Oral Tales from India KIRIN NARAYAN

SCHNePel, Die Dschungelkönige: Etbnobistorische Aspekte von Politik und Ritual in Südorissa/Indien PETER GAEFFKE 
Subrahmanyam, The Career and Legend of Vasco da Gama

Tartakov, The Durga Temple at Aibole: A Historiographical Study

Southeast Asia

CAR EY (ed.), Burma: The Challenge of Change in a Divided Society

MARY P. CALLAHAN

GILL and MAK (eds.), Arms, Transparency and Security in Soutb-East Asia

DONALD HINDLEY

GroßheIM, Nordvietnamesische Dorfgemeinschafte: Kontinuität und Wandel

JOHN KLEINEN

KOLTYK, New Pioneers in the Heartland: Hmong Life in Wisconsin

ELIZABETH COVILLE

Kr Atosk a (ed.), Malaya and Singapore During the Japanese Occupation

DONNA J. AMOROSO

KUMAR, Java and Modern Europe: Ambiguous Encounters .

JEAN GELMAN TAYLOR

PeLras, The Bugis

LEONARD Y. ANDAYA

Pertier RA, Philippine Localities and Global Perspectives

BRIAN M. HOWELL

SCHILle R and MARTIN-SCHILLER (eds.), Imagining Indonesia: Cultural Politics and Political Culture FELICIA HUGHES-FREELAND

StUART-Fox, A History of Laos

DAVID K. WYATT

UHLIN, Indonesia and the "Third Wave of Democratization": The Indonesia ProDemocracy Movement in a Changing World

\title{
Other Books Received 1234
}

Errata 1238

Obituaries

\author{
M. Athar Ali (1925-1998) \\ WARREN S. HunSBERger (1911-1997) \\ OCtavio Paz (1915-1998) \\ R. Suntharalingam (1936-1998)
}

RICHARD B. BARNETT

DAVID HUNSBERGER

LAWRENCE SAEZ

PAUL H. KRATOSKA

\section{Annual Volume Contents 1244}

Contributors 1255 


\title{
The Journal of Asian Studies
}

\author{
University of Utah, Salt Lake City, Utah 84112
}

Editorial Board. Editor: ANAND A. YANG, University of Utab. Assistant Editors: China, ANN WALTNER, University of Minnesota; Japan, ANNE WALTHALL, University of California, Irvine; Korea, JaHYUn Kim HabOuSH, University of Illinois; South Asia, AmRITA BASU, Amberst College; Southeast Asia, Barbara Watson ANDAYA, University of Hawaii. Book Review Editors: China, (Modern) JoAn Judge, University of California-Santa Barbara, (Premodern) MiChael A. Fuller, University of California-Irvine, Inner Asia, Nicola Di COSMO, Harvard University; Japan, ANN SHERIF, Oberlin College; Korea, Mark Peterson, Brigham Young University; South Asia, William R. PinCH, Wesleyan University; Indira Viswanathan Peterson, Mount Holyoke College; Southeast Asia, Juliane SCHOBER, Arizona State University.

Editorial Staff. Manuscript Editors: Cathy Council, Terri K. Borchers and Tessa Hauglid. Administrative Secretary: BrIDGID BeST. Editorial Assistant: MiCHELle Call, University of Utah.

Sponsoring Institutions. University of Michigan, University of Utah.

The Journal of Asian Studies (ISSN 0021-9118), founded in 1941 and known until September 1956 as the Far Eastern Quarterly, is published by the Association for Asian Studies (formerly The Far Eastern Association) in February, May, August, and November. The annual institurional subscription rate for the Joumal is $\$ 60$, for non-U.S. subscribers $\$ 70$, postage included. Regular members of the Association for Asian Studies receive the Journal as part of their annual membership. Single issues of the Journal published after February 1974 are available through the Secretariat of the Association. Issues published prior to 1958 may be purchased from A.M.S. Reprints, 56 East 13 th Street, New York, NY 10003.

\section{GUIDELINES FOR SUBMISSION OF MANUSCRIPTS}

Completed manuscripts, inquiries about material for possible publication, and correspondence to the editor should be sent to the Journal's editorial offices:

$$
\begin{aligned}
& \text { Anand A. Yang, editor } \\
& \text { The Journal of Asian Studies } \\
& 2150 \text { LNCO } \\
& \text { University of Utah } \\
& \text { Salt Lake City, Utah } 84112 \\
& \text { U.S.A. }
\end{aligned}
$$

Phone: 801-585-7269

Fax: 801-585-3510

E-mail: Anand.Yang@m.cc.utah.edu

Article manuscripts, including notes, should not exceed 40 pages in length. Please submit four copies and a disk (preferably formatted to WordPerfect 5.1). All submitted work should be double-spaced, including extracts, notes, and references. Consult recent issues of the Journal as a guide to format. Footnotes should be as few as possible, and typed double-spaced at the end of the text. Documentation should follow the style recommended in sections 16.3 through 16.28 of the Cbicago Manual of Style, 14th ed. (Chicago: University of Chicago Press, 1993), pp. 641-51. Authors are encouraged to submit tables, figures. maps, photographs, and other illustrations along with their manuscripts; please consult the editor for specifications. Additional guidelines on manuscript preparation will be sent upon request.

All manuscripts submitted to the JAS are expected not to have been published elsewhere and not be under review for possible publication elsewhere. Unsolicited book reviews are not accepted.

Books for review and correspondence concerning reviews should be sent to the appropriate book review editor:

Asia General: Anand A. Yang (address above)

China: Modern-Joan Judge, Dept. of History, University of California-Santa Barbara, Santa Barbara, CA 93106. Premodern-Michael A. Fuller, Dept. of East Asian Language and Literature; University of California-Irvine, mail Code 6000, Irvine, CA 92697-6000

Inner Asia: Nicola Di Cosmo, East Asian Languages and Civilizations, Harvard University, Cambridge, MA 02138

Japan: Ann Sherif, East Asian Studies, Peters Hall, Oberlin College, Oberlin, OH 44074-1091

Korea: $\quad$ Mark Peterson, David M. Kennedy Center, Brigham Young University, Provo, UT 84602

Soutb Asia: William R. Pinch, Department of History, Wesleyan University, 348 Church Street, Middletown, CT 06459-0002; Indira Viswanathan Peterson, Asian Studies Program, Mount Holyoke College, South Hadley, Mass. $01075-6454$

Southeast Asia: Juliane Schober, Department of Religious Studies, Arizona State University, Tempe, AZ 85287. 3104

Articles in The Journal of Asian Studies represent neither the views of the Association for Asian Studies nor those of the JAS editors. The editor is responsible for the final selection of the content of the Journal and reserves the right to reject any material deemed inappropriate for publication. Responsibility for opinions expressed and for the accuracy of facts published in articles and reviews rests solely with the individual authors.

Requests for permission to reprint and all correspondence regarding membership, subscriptions, advertising, or business should be addressed to the Association for Asian Studies, 1 Lane Hall, University of Michigan, Ann Arbor, MI 48109. The Journal is indexed in the Sorial Sciences \& Humanities Index and Book Review Index and abstracted in Historical Abstratts and A merica: History and Life. It is also available on film through University Microfilms, Ann Arbor, MI 48109.

Periodicals postage paid at Ann Arbor, Michigan. POSTMASTER: Send address changes to The Association for Asian Studies, 1021 East Huron Street, Ann Arbor, MI 48104. 